\title{
Can I Be Myself Around Natives?
}

\section{Feelings of Inauthenticity Mediate the Relationship Between Perceived Discrimination and Tendencies to Avoid Friendships With Natives Among Refugees in Germany}

\author{
Christina Anna Bauer@ and Bettina Hannover
}

Department of Educational Science and Psychology, Freie Universität Berlin, Germany

\begin{abstract}
The social integration of the ever-growing number of refugees in receiving societies is of major importance. Perceived discrimination has been found to predict fewer friendships with natives over time. But what short-term mechanisms explain this effect? In a sample of 115 refugees living in Germany we (i) replicated the long-term discrimination-social-integration relationship, (ii) found short-term associations between discrimination and affective, motivational, and behavioral tendencies not to befriend natives, and (iii) showed authenticity to mediate this short-term relationship: with increasing discrimination, refugees felt less like they could show their authentic selves around natives, which in turn impaired tendencies to befriend natives. Discrimination may impede the formation of interethnic friendships by instilling feelings of inauthenticity. Implications for prevention measures are discussed.
\end{abstract}

Keywords: refugees, authenticity, discrimination, friendships, social integration

According to the United Nations High Commissioner for Refugees (2019), the number of refugees around the world is at a record high. By the end of 2018, 70.8 million people were forcibly displaced - that is, 2.3 million more than in the previous year. With growing threats arising from climate change and political tensions, these numbers are expected to continue to rise.

One of the most important tasks connected to the increasing number of forced migrants is the social integration of these newly arrived individuals in receiving societies. While strong ties to family and same-ethnic friends are crucial for migrants' well-being (Berry, Phinney, Sam, \& Vedder, 2006; Merz \& Huxhold, 2010; Yip, Wang, Mootoo, \& Mirpuri, 2019), the formation of social connections with natives is thought to improve intergroup relationships, social cohesion (e.g., Hewstone, 2015; Pettigrew \& Tropp, 2006), as well as migrants' integration in domains such as language acquisition, or job placement (Esser, 2001; Lancee, 2012).

Previous research indicates that the recent rises in anti-immigrant hostility and connected acts of hostile discrimination in the Western World (German Federal AntiDiscrimination Agency, 2017; German Federal Ministry of the Interior, 2016; Hangartner, Dinas, Marbach, Matakos, \& Xefteris, 2019) may pose a barrier to social integration: Several studies conducted with non-refugee migrant and ethnic minority groups found perceived discrimination to predict more same-ethnic friendships and - importantly
- few friendships with native majority group members (Franco, 2019; Levin, Van Laar, \& Sidanius, 2003; Titzmann, Silbereisen, \& Schmitt-Rodermund, 2007). However, it is not yet well understood, how this association between perceived discrimination and segregated friendship patterns comes about. We aim to shed light on short-term processes that could contribute to the negative relationship between discrimination and interethnic friendships as a crucial component of integration. Based on the State Authenticity as Fit to Environment (SAFE) model (Schmader \& Sedikides, 2018) that describes individuals' sense of authenticity as a driving force in self-segregational tendencies, we investigate authenticity as a potential mediator between perceived discrimination and individuals' tendencies to avoid friendships with natives. Discrimination constitutes a form of social rejection that is based on individuals' social identity. Since individuals' social ingroup identities (e.g., being Syrian) constitute important parts of their selves (Tajfel \& Turner, 1979), perceptions of discrimination may affect the extent to which individuals can be authentic - that is, expressing their core selves - around members of groups who are thought to perpetrate discrimination (e.g., natives). Aversive feelings of inauthenticity may in turn reduce individuals' tendencies to befriend members of discrimination perpetrating groups and thus contribute to the link between perceived discrimination and reduced interethnic friendships.

We investigate this issue in a sample of refugees in Germany. This article is one of the first to shed light on 
the social integration of the growing number of refugees in the Western world. Forced to leave their previous social networks behind, the social integration of refugees in receiving societies may be of particular importance. Germany is among the countries with the highest numbers of refugee migrants in the West (McCarthy, 2018). As many other Western nations, Germany has also recently experienced a rise of anti-immigrant hostility (Rooduijn, 2015), which makes the question of how discrimination may affect refugees' social integration ever more important.

\section{Authenticity}

Authenticity has been defined as the extent to which a person can express their true core self - including their inner values, desires, and feelings - in a given environment (Harter, 2002; Kernis \& Goldman, 2006). People act authentically when they feel they can simply be themselves without having to self-monitor or control the impressions they convey to others (Lenton, Bruder, Slabu, \& Sedikides, 2013).

While authenticity and inauthenticity are both commonly experienced by humans (Lenton et al., 2013), people generally strive for authenticity, which is associated with more positive affect, higher need fulfillment, and wellbeing (Harter, Marold, Whitesell, \& Cobbs, 1996; Leak \& Cooney, 2001; Lenton et al., 2013). Authenticity has also consistently been linked with higher relationship quality (Josephs et al., 2019; Lopez \& Rice, 2006; Swann, De La Ronde, \& Hixon, 1994), indicating that being honest and open toward others may be an important element of close relationships (Josephs et al., 2019). Research that connects authenticity to experiences of positive affirmation, secure attachment, and unconditional regard (Didonato \& Krueger, 2010; Gillath, Sesko, Shaver, \& Chun, 2010; Harter et al., 1996) suggests that in order to be able to feel authentic, individuals need to feel accepted. Conversely, individuals seem to experience a heightened sense of inauthenticity when they anticipate that they may be rejected by others, as indicated by research associating inauthenticity with rejection sensitivity and feelings of being evaluated (Josephs et al., 2019; Snyder, 1987).

In line with this reasoning, ethnic minorities have been shown to respond with increased feelings of inauthenticity, when they perceived their social ingroup - a central component of individuals' self (Tajfel \& Turner, 1979) - to be rejected (Shelton, Richeson, \& Salvatore, 2005): Compared to a control condition, African Americans who were told that anti-African American prejudice was still very common among White US-Americans, reported an increased sense of inauthenticity and negative affect in a subsequent interaction with a White conversation partner. Although their White interaction partners were blind to condition, African
Americans' perception of White people's hostility toward their ingroup shaped their experiences of authenticity in these interactions. In this research, we investigated whether a similar pattern would show for refugee migrants in Germany and whether, in the field, too, the perceived prevalence of hostility toward individuals' ingroup would shape their sense of authenticity in interactions with the majority group.

\section{Authenticity and Self-Segregation}

In this research, we build on the SAFE model of Schmader and Sedikides (2018), which assumes that individuals' desire for authenticity and avoidance of inauthenticity contributes to self-segregation in diverse domains. Based on evidence for occupational self-segregation by gender (Peterson \& Morgan, 1995), housing self-segregation by race (Ihlanfeldt \& Scafidi, 2002), and social segregation in friendships (Bonilla-Silva \& Embrick, 2007; Titzmann \& Silbereisen, 2009), Schmader and Sedikides (2018) hypothesized that individuals who share a social identity would cluster together in certain environments which allow them to show their true selves, and they would conversely avoid environments in which they expect to feel inauthentic.

Environmental cues that signal a high fit of individuals' social identity - like the existence of salient role models who are perceived to be similar to oneself (Cheryan, 2012; Cheryan, Drury, \& Vichayapai, 2013; Hall, Inness, Schmader, Aday, \& Croft, 2018) - can, according to Schmader and Sedikides (2018), help individuals develop a sense of authenticity. In contrast, environmental cues that signal a low fit of individuals' social identity in a given environment - like a low representation of people who share that social identity (Purdie-Vaughns, Steele, Davies, Ditlmann, \& Crosby, 2008) or the perceived discrimination of people with a shared social identity as investigated in this work - are predicted to impair individuals' authenticity and make them hesitant to show their true selves around others. Based on individuals' shared motivation to approach situations in which they feel authentic and avoid inauthentic situations, individuals with the same social identity are predicted to over time cluster together in environments that signal a high fit and acceptance of individuals' social identity and thus facilitate their sense of authenticity.

While much research supports the assumption that environmental cues can signal a sense of fit to individuals based on their social identity and thus lead them to approach or avoid this environment (Cheryan, Plaut, Davies, \& Steele, 2009; Hall et al., 2018; Murphy, Steele, \& Gross, 2007; Purdie-Vaughns et al., 2008), the proposed mediational role of authenticity in these processes - a crucial prediction of 
the SAFE model - remains to be tested. This work aims to start filling this lack of empirical work by investigating the role of authenticity in mediating the relationship between environmental cues - in this case, natives' identity-based discrimination as perceived by refugees - and refugees' tendencies to avoid (inauthentic) interactions with natives.

\section{Immigrants' Friendship Formation}

When comparing immigrants same-ethnic ad interethnic friendships, research indicates that immigrants generally tend to report relatively few friendships with members of the majority ethnic group of the receiving country than with people who share their ethnic background (e.g., Leszczensky \& Pink, 2017; Titzmann, Silbereisen, \& Mesch, 2012) - especially in the initial stage of the integration process (Titzmann \& Silbereisen, 2009). The percentage of immigrants' intra-ethnic friends has been shown to decrease and the share of native friends to increase with time spent in the receiving country, until leveling off at a more stable rate (Titzmann, 2014; Titzmann \& Silbereisen, 2009; Titzmann et al., 2012). Overall, however, the share of native friends still remains smaller than would be expected by chance (Titzmann \& Silbereisen, 2009; Titzmann et al., 2012) - even for ethnic minorities who were born and raised in the country of residence (Aboud, Mendelson, \& Purdy, 2003; Baerveldt, Van Duijn, Vermeij, \& Van Hemert, 2004). While it is assumed that these friendship patterns at least partly reflect immigrants' own preference for same-ethnic friends (Franco, 2019; Titzmann, 2014; Titzmann et al., 2007), it should also be kept in mind that natives likely contribute to segregated friendship patterns as well. Natives often show hostile, unwelcoming attitudes toward immigrants (see Titzmann, 2017, for a review), resulting in social barriers that contribute to segregated friendship patterns, too.

In our study, we focus primarily on friendships with natives rather than intra-ethnic friendships, since previous research has highlighted the particular importance of these social connections. While intra-ethnic friendships may fulfill important psychological functions, such as reassurance about one's own cultural identity (Hoare, 2019), they cannot replace inter-ethnic friendships. Interethnic-friendships may for example reduce acculturative stress (Castillo, Cano, Chen, Blucker, \& Olds, 2008) and support individuals' overall integration by generating significant social capital (Bourdieu, 1987) needed to be successful in the receiving society (e.g., Lancee \& Hartung, 2012; Roth, 2013; Werum, 2000). For the larger society, too, interethnic friends are an important basis for social cohesion, since they improve interethnic relationships (e.g., Hewstone, 2015; Pettigrew \& Tropp, 2006) and may even reduce the risk of radicalization due to marginalization (Lyons-Padilla, Gelfand, Mirahmadi, Farooq, \& Van Egmond, 2015).

\section{Discrimination and Friendship Formation}

Discrimination can affect those discriminated against in diverse ways. Instances of discrimination oftentimes lead to direct disadvantages for the targets of discrimination in relevant domains, like in a situation in which a person does not get a job or a rental contract based on their social identity. Above and beyond the actual occurrence of discrimination, the subjective perception of discrimination also carries pervasive negative effects on the psychological and behavioral level. Amongst others, previous longitudinal research has shown perceived discrimination to be connected to decreased wellbeing, heightened anxiety, stress, substance abuse, conduct problems, and educational performance (Borsch et al., 2019; Brody et al., 2006; da Silva Rebelo, Fernández, \& Achotegui, 2018; Gibbons, Gerrard, Cleveland, Wills, \& Brody, 2004; Levin, Van Laar, \& Foote, 2006; Suleman, Garber, \& Rutkow, 2018). With regard to intergroup processes, research indicates that perceived discrimination may cause ethnic minorities to turn away from the majority group and toward their ethnic ingroup. Perceived discrimination has for example been associated with stronger disidentification from the majority group (Jasinskaja-Lahti, Liebkind, \& Solheim, 2009; Matschke \& Sassenberg, 2010; Verkuyten \& Yildiz, 2007), as well as increased ethnic identity exploration (Branscombe, Schmitt, \& Harvey, 1999; Pahl \& Way, 2006; Ramos, Cassidy, Reicher, \& Haslam, 2012; Verkuyten \& Yildiz, 2007).

Relatedly, perceived discrimination has also been connected to more segregated friendship patterns over time: The more discrimination ethnic minority members report, the more they tend to have same-ethnic minority rather than ethnic majority friends (Franco, 2019; Levin et al., 2003; Titzmann et al., 2007). Similarly, ethnicity-based rejection sensitivity - the anxious expectation to be rejected because of one's ethnic background - has been associated with segregated friendship patterns. Interestingly, no discriminationfriendship-segregation association was found in some studies with a cross-sectional design (Titzmann, Serwata, Silbereisen, \& Davidov, 2016; Titzmann et al., 2007) and/or non-visible minorities (Titzmann \& Silbereisen, 2009; Titzmann et al., 2007. These findings indicate that (i) visible minorities (such as most of the refugees recently arrived in the West) may be more susceptible to the effects of discrimination (Levin et al., 2003; Walton \& Cohen, 2007), and (ii) effects of discrimination on friendship patterns may need time to develop, showing longitudinally, but not necessarily cross-sectionally. 


\section{Affective, Motivational, and Behavioral Tendencies to Avoid Friendships With Natives}

Why, however, are perceptions of discrimination connected to a lower number of native friends? It could be argued that perceived discrimination constitutes a proxy for an individuals' overall social exclusion emanating from natives, which is connected to a reduced number of interethnic friends. In addition, it is also possible that perceived discrimination weakens refugees' inclination to actively reach out to natives. Such self-segregational tendencies would indicate an impairment in immigrants' ability to make use of existing opportunities for potentially valuable interethnic connections. Both processes - one driven through natives and one primarily through migrants - may very well simultaneously be at play and together contribute to the link between discrimination and interethnic friendships. In this research, we specifically focused on migrants' tendencies to befriend natives. While a reduction in anti-immigrant hostility and connected discrimination rates should always be the primary goal and much research is already focusing on this endeavor (e.g., Bauer \& Hannover, 2020; Brauer \& Er-Rafiy, 2011; Pettigrew \& Tropp, 2006), it will be difficult to prevent any and all experiences of discrimination. We therefore considered understanding and improving the way individuals respond to experiences of discrimination to be crucial.

To get a comprehensive view of relevant processes, the tendency to befriend natives was measured on an affective, motivational, and behavioral level. Affective tendencies refer to individuals' anticipation to feel negative emotions during encounters with natives (expected affect), which are crucial determinants of individuals' future behavior (Livingston \& Drwecki, 2007; Tugade, Shiota, \& Kirby, 2014). Motivational tendencies were operationalized as the extent to which individuals generally wish to be integrated in German society (integration motivation). Behavioral tendencies were measured as individuals' anticipation whether they would engage in such an encounter if an opportunity arises (behavioral engagement; cf. Oettingen \& Mayer, 2002). In particular, we assessed anticipated response to an invitation for a party with natives.

\section{The Present Research}

In this research, we aimed to (i) replicate the previously found long-term relationship between discrimination and fewer native as well as more intra-ethnic friends, (ii) investigate short-term associations between discrimination and affective, motivational, and behavioral tendencies not to befriend natives, and (iii) test authenticity as a mediator for this short-term relationship.

We thus include data from two time points: At time 1 (t1), only perceived discrimination was assessed. At time 2 ( $\mathrm{t} 2)$, we measured perceived discrimination, authenticity, affective, motivational, and behavioral tendencies related to the formation of friendships with natives, as well as individuals' friendship patterns. Since affective, motivational, and behavioral tendencies related to the formation of friendships with natives were exclusively measured in the survey of time 2, we could conduct cross-sectional analyses on these variables at time 2 only. To assess friendship patterns, we had participants list their friends and their friends' ethnicity. Our specific hypotheses were as follows.

Hypothesis 1 (H1): Perceived discrimination of one's ingroup at time 1 is connected to a lower number of close native friends, but a higher number of intraethnic friends at time 2.

Hypothesis 2 (H2): Cross-sectionally, perceived discrimination at time 2 is negatively correlated with individuals' sense of authenticity and affective, motivational, and behavioral tendencies related to the formation of friendships with natives - specifically with individuals' anticipation how they would feel in interactions with natives (expected affect), individuals' motivation to integrate in the German society (integration motivation), and individuals' anticipated behavioral engagement in encounters with natives (behavioral engagement).

Hypothesis 3 (H3): At time 2, authenticity mediates the effect of perceived discrimination on affective, motivational, and behavioral tendencies not to befriend natives.

\section{Method}

\section{Procedure}

Data were derived from a larger project with refugees in Germany. Refugees were recruited through refugee shelters, social organizations, as well as an online social platform. In sum, we contacted 384 organizations via email or phone and posted 246 invitations in Facebook groups. Once participants had registered for our project, surveys were sent out online through email or an app. As incentives, participants received $10 €$ or a voucher for an online shopping portal for the same value for their participation in this research project. 
The project incorporated a total of three surveys. Data were taken from Surveys 2 and 3 (which will be referred to as time 1 and 2 for the purpose of this study). Survey 2 was implemented in spring 2018 (3 months after individuals had completed Survey 1). Survey 2 included our predictor perceived discrimination and no other measures addressed in the current study. Survey 3 was sent out 6 months after Survey 2. Survey 3 , which served as the focus of our analyses, included measures of perceived discrimination, number of native and intra-ethnic friends, authenticity, and motivational as well as behavioral variables relating to friendship formation. Materials (including all translations) as well as data are available on the Open Science Framework https://osf.io/ks9mu/?view_only=65843002d32d4cf 58adf3d7f94d7cbc2

\section{Participants}

A total of 299 refugees participated in the research project. However, only participants who completed the relevant measures could be included in our analyses. Thus, data from a total of 115 participants, who had completed Survey 3 , were included in this study. While our main crosssectional analyses of Survey 3 included all of these 115 participants, analyses replicating the previous long-term association between discrimination and friendship segregation with data from Surveys 2 and 3 included a subpopulation of 75 participants.

Prior to the execution of our study, power analyses were conducted. Based on estimated medium effect sizes similar to previous studies (Franco, 2019; Levin et al., 2003; Titzmann et al., 2007), power analyses using $G^{*}$ Power (Faul, Erdfelder, Lang, \& Buchner, 2007) with a power level of .80 indicated a minimum sample size of 64 participants for the long-term association between discrimination and friendship patterns (estimated effect size $r^{2}=.3$ ), and 68 participants for cross-sectional correlations and regressions underlying mediational analyses (estimated effect sizes, $r^{2}=.3$ and $f^{2}=.15$ ).

Demographics of the total sample were as follows. The gender distribution was 35\% female, $57 \%$ male, and $8 \%$ preferred not to indicate their gender. The average age was $M=26.68(S D=8.57)$. Participants reported coming from diverse African and Middle Eastern countries. Most participants reported coming from Syria (30\%), Iran (25\%), or Afghanistan (21\%). The average duration of stay in Germany (reported at the beginning of the project) was $M=1.90$ years $(S D=0.90)$.

\section{Measures}

All measures were translated into German, Arabic, and Farsi. In order to create these translations, individuals who were fluent in both English and the respective language translated the English version back and forth. Discrepancies were solved through discussion.

\section{Perceived Discrimination}

To assess individuals' perceived discrimination, a measure developed by Diehl, Fischer-Neumann, and Mühlau (2016) was adapted. At both time points, participants were asked: "Some say that people from your country are being discriminated against in Germany. How often do you think people from your country are discriminated against in Germany?" Responses ranged from 1 (never) to 5 (very often). On average, participants reported slightly higher perceived discrimination at time $2(M=3.46, S D=1.39)$, compared to time $1(M=3.34, S D=1.37)$. This difference was not significant, $p=.13$.

\section{Friendships}

In order to assess friendship patterns, at time point 2 we asked participants to list their friends by indicating their first names or fictitious names. Participants could list up to eight friends and were instructed to list "only really close friends". The friends' origins were assessed on the following page. Participants were asked to indicate for each listed friend, whether he or she was from Germany, from the individuals' country of origin or from a third country. On average, participants listed 3.37 friends $(S D=3.00)$, of which an average of 1.37 were intra-ethnic friends $(S D=$ $1.80), 1.65$ were German friends $(S D=2.41)$ and 0.51 were friends from a third country $(S D=1.10)$.

\section{Authenticity}

To assess individuals' sense of authenticity in interactions with Germans at time 2, participants were asked how much they agreed to the following two items adapted from English and John (2013): "It is easy to express my true attitudes and feelings during interactions with Germans" and "I can be myself with Germans". Responses ranged from 1 (strongly disagree) to 5 (strongly agree). The scale demonstrated sufficient reliability, $\alpha=.72$.

\section{Behavioral Engagement}

To assess behavioral tendencies to engage with Germans when opportunities arise at time 2, participants were presented with the following scenario: "Imagine someone knocks at your door. It is your German neighbor you have not met before. He invites you to his party and you don't have any plans yet. How likely are you to go to the party?" Responses could be given on a scale from 1 (very unlikely) to 5 (very likely).

\section{Expected Affect}

To assess expectations how one would feel in interactions with Germans at time 2, participants were further 
asked: "Imagine you decided to go to the party. There are only Germans and no other immigrants. How would you feel being at the party and interacting with the people?" Participants specifically indicated how much they would agree to the following four statements: "It would be easy for me to approach people and start a conversation", "I would feel comfortable", "I would enjoy it" and "I would feel anxious" (reverse coded). Responses ranged from 1 (strongly disagree) to 5 (strongly agree). The scale demonstrated sufficient reliability, $\alpha=.73$.

\section{Integration Motivation}

To assess individuals' motivational tendencies to integrate into the German receiving society at time 2, participants were asked how much they agreed to six items, addressing (i) social connections (e.g., "One of my most important goals is to get to know the people in Germany"), (ii) the perspective to stay in Germany (e.g., "Even if I could easily move to another country, I would in any case stay in Germany"), and (iii) learning German (e.g., "If I could wish for something, it would be to be in perfect command of the German language!"). Responses ranged from 1 (strongly disagree) to 5 (strongly agree). The scale demonstrated high reliability, $\alpha=.84$.

\section{Results}

\section{Long-Term Relationship Between Discrimination and Number of Native and Non-Native Friends}

We tested whether perceived discrimination predicts a more segregated friendship pattern over time, and regressed discrimination at time 1 onto the number of reported friends at time 2. Discrimination at time 1 was associated with fewer native friends, $\beta=-.23, p=.048$, but more intra-ethnic friends at time $2, \beta=.37, p=.001$. The overall number of friends that participants reported was not affected by previously experienced discrimination, $\beta=.07, p=.56$. Similarly, the number of friends from third countries (i.e., friends that came neither from Germany nor the immigrant's respective country of origin) did not differ depending on levels of discrimination, $\beta=.16, p=.18$.

\section{Cross-Sectional Correlations of Discrimination With Authenticity and Tendencies Not to Befriend Natives}

As evident in Table 1, correlative analyses support our second hypothesis: at time 2, perceived discrimination was negatively associated with authenticity as well as affective, motivational, and behavioral tendencies to befriend natives. In support of Hypothesis 2, individuals who perceived higher discrimination reported to feel less authentic in interactions with Germans, they expected to feel worse in future interactions with Germans (expected affect), showed lower motivation to integrate in Germany (integration motivation), and were less likely to report that they would go to a party with Germans (behavioral engagement).

\section{Indirect Effects of Discrimination Through Authenticity}

We conducted mediation analyses following Preacher and Hayes (2004) to test indirect effects of perceived discrimination at $\mathrm{t} 2$ through authenticity on affective, motivational and behavioral tendencies not to befriend natives. As expected, we found significant indirect effects of perceived discrimination through authenticity on expected affect concerning interactions with Germans, $a b=-.05, S E=.02$, $95 \%$ CI $[-0.09,-0.01]$, on integration motivation, $a b=$ $-.03, S E=.02,95 \% \mathrm{CI}[-0.06,-0.01]$, and on behavioral engagement with natives, $a b=-.06, S E=.03,95 \% \mathrm{CI}$ $[-0.12,-0.02]$. While no significant direct effect of discrimination remained for integration motivation, $c=-.07$, $S E=.05,95 \%$ CI $[-0.16,0.02]$, a significant direct effect of discrimination was still observed for expected affect, $c=-.17, S E=.04,95 \% \mathrm{CI}[-0.27,-0.08]$, and behavioral engagement, $c=-.13, S E=.06,95 \%$ CI $[-0.26,-0.004]$. In sum, Hypothesis 3 was thus supported. Individuals who experienced more discrimination felt to a lesser extent that they can be themselves in social interactions with Germans. This reduced feeling of authenticity in turn resulted in expectations of more negative affect regarding interactions with Germans, weaker overall integration motivation, and lower engagement with natives.

\section{Discussion}

This paper aims to examine processes that could explain the previously found link between discrimination and immigrants' low number of native friends. We investigate this issue in a population of refugees. Since refugees have not come to the receiving country voluntarily, cannot return to their home country, and in many cases had to leave family and friends behind, the formation of new social relationships in the receiving society is of special importance for this increasingly large group of migrants.

Replicating earlier findings, we found that perceived discrimination was connected to a more segregated friendship 
Table 1. Correlations, means $(M)$, and standard deviations (SD) of psychological constructs at time 2

\begin{tabular}{|c|c|c|c|c|c|c|c|}
\hline \multirow[b]{2}{*}{ Variable } & \multirow[b]{2}{*}{ M } & \multirow[b]{2}{*}{$S D$} & \multicolumn{5}{|c|}{ Correlations } \\
\hline & & & 1 & 2 & 3 & 4 & 5 \\
\hline 1. Discrimination & 3.46 & 1.39 & 1 & $-.23^{\star}$ & $-.26^{*}$ & $-.38 * \star$ & $-.21 *$ \\
\hline 2. Authenticity & 3.73 & 0.99 & & 1 & $.41 * \star$ & $.45^{\star \star}$ & $.30 * \star$ \\
\hline 3. Behavioral engagement with natives & 4.08 & 1.02 & & & 1 & $.60 \star \star$ & $.39 * *$ \\
\hline 4. Expected affect & 3.80 & 0.82 & & & & 1 & $.34 * \star$ \\
\hline 5. Integration motivation & 4.30 & 0.70 & & & & & 1 \\
\hline
\end{tabular}

Note. ${ }^{\star} p<.05 ;{ }^{*} p<.01$ (two-tailed).

pattern with less native and more same-ethnic friends 6 months later. In order to investigate how the long-term association between discrimination and reduced numbers of interethnic friendships may come about, we conducted cross-sectional analyses at time 2. Analyses showed that perceived discrimination was related to processes relevant for the formation of interethnic friendships. In particular, we found that with higher perceived discrimination individuals reported weaker affective, motivational, and behavioral tendencies to befriend natives. Importantly, refugees' sense of authenticity, that is, their feeling that they can be themselves in interactions with others, appeared to be a key variable in this process, mediating the effects of discrimination on individuals' affective, motivational, as well as behavioral tendencies to form friendships with natives. Consistent with the assumptions of the SAFE model (Schmader \& Sedikides, 2018), the more discrimination refugees experienced, the less they felt like they could show their true selves around natives, which in turn seemed to reduce their inclination to befriend natives. This finding supports the idea that feelings of inauthenticity in interactions with natives that are sparked by experiences of discrimination may cause refugees to turn away from natives. Given individuals' strong motivation for authentic interactions (Lenton et al., 2013) and the association of inauthentic experiences with negative affect and worse wellbeing (Leak \& Cooney, 2001; Lenton et al., 2013), a shift away from natives may be emotionally adaptive.

We think that this research has a number of strengths and makes relevant contributions to both, theory and practice. Firstly, this is one of the first papers examining the social integration of refugees recently immigrated to the western world. Our study sample serves as an example for the growing refugee populations that migrate from mostly African and Middle Eastern countries to the western world. While learning about the ways we can support the integration of this population is of growing importance, research is still very scarce - probably in part because it is difficult to conduct. Such difficulties concern, for example, the population's limited literacy (Scheible, 2018), the diversity of languages and dialects spoken (Neske, 2017), as well as recruiting difficulties due to limited institutional access to refugees and refugees' frequent relocations. With this work, we respond to the ever-growing urgency to learn about the social integration process of this understudied population.

Secondly, with reduced feelings of authenticity, we identified an important mediating micro-process which seems to at least partly explain the association between perceived discrimination and tendencies not to befriend natives. This finding sheds light on how the previously found association between discrimination and segregated friendship patterns (Franco, 2019; Levin et al., 2003; Titzmann et al., 2007) comes about. It also empirically substantiates the assumption of the SAFE model (Schmader \& Sedikides, 2018) that individuals' sense of authenticity constitutes a crucial factor in self-segregational processes. To our knowledge, our study was the first to put this assumption to the test and confirm the mediating role of authenticity in the case of the perceived discriminatory cues and ethnic self-segregation. Beyond theory, our findings may also help practice develop measures that could buffer the detrimental effects of discrimination on refugees' social networks by addressing individuals' sense of authenticity.

Thirdly, we improve on earlier measures of tendencies to form segregated friendship patterns. To assess friendship networks, previous research has mostly used Likert-Scales (e.g., Franco, 2019) that give a rough estimate about friendship patterns or questions about the number of individuals' same-ethnic versus native friends (e.g., Levin et al., 2003; Titzmann \& Silbereisen, 2009). In contrast, we had participants list each friend and - in a separate step - indicate their ethnic background. This method may yield more accurate and detailed information including information about the overall numbers of friends and third-country friends, and may thus be useful for future research, too. Furthermore, we assessed processes that precede friendship selection - specifically affective, motivational, and behavioral tendencies to form friendships with natives. The perception of discrimination presumably does not cause immediate changes in friendship networks, but may trigger initial mental and behavioral processes that could translate into a change in friendships on the long run. To our knowledge, this is the first study directly assessing such short-term procedural correlates of discrimination. 
Lastly, improving on the study design of many earlier studies on the relationship between discrimination and friendship patterns, we could realize a longitudinal research design, assessing friendships approximately six months after individuals' perceptions of discrimination. This approach carries two advantages over commonly used cross-sectional designs. On the one hand - while causal claims should still be tested with other methods in future research - compared to a cross-sectional correlation, a covariation between discrimination and friendships observed over time is a somewhat more robust indicator for a potentially causal relationship. On the other hand, the longitudinal design allowed us to reveal associations that may be less likely observed in cross-sectional studies. Indeed, previous studies examining the discriminationfriendship relationship cross-sectionally often failed to find significant associations (Titzmann et al., 2016, 2007). Since the effects of discrimination on temporarily rather stable friendship patterns likely take some time to develop, longitudinal study designs like ours may be more adequate to investigate this relationship.

\section{Limitations and Future Research}

Our work raises important questions for future research to investigate. Firstly, future studies should use different methods that complement our correlational field-study design to assess the relationship between discrimination, authenticity, and friendship formation processes from different angles. Laboratory experiment and/or cross-lagged panel analyses should be used to test the causal relationship between variables. While laboratory experiments could be used to test short-term motivational and behavioral consequences of salient discrimination experiences, cross-lagged panel studies could be used to further examine the longterm effects of discrimination on friendship patterns. In addition, daily diary studies could be conducted assessing experiences of discrimination and connected variations in authenticity as well as motivational and behavioral variables related to interethnic friendship formation. Together, these studies could provide us with a comprehensive picture about the relationship between discrimination and friendship formation processes.

Secondly, future research should also explore the role of potential additional variables relevant in the relationship between perceptions of rejection (such as discrimination) and self-segregation. Further research should examine if our findings would generalize across different forms of rejection, other than perceptions of discrimination. According to the SAFE model (Schmader \& Sedikides, 2018), any environmental cue which signals a low fit of individuals in a given environment should trigger feelings of inauthenticity and thus self-segregational tendencies. Instead of perceived discrimination, refugees' perception about natives' stereotypes (meta-stereotypes; e.g., Kamans, Gordijn, Oldenhuis, \& Otten, 2009) could for example be explored as alternative sources of threat to individuals' sense of authenticity and social integration. In addition, future research should also test potential additional mediators of the relationship between perceived discrimination and self-segregational tendencies. It is well conceivable that the discriminationsegregation relationship could be mediated not only by authenticity, but also by other variables: Perceptions of discrimination likely trigger negative attitudes and cognitions toward natives (Hindricks, Verkuyten, \& Coenders, 2014) or doubts about one's belonging in a given setting (Martiny $\&$ Nikitin, 2019). These processes could further contribute to self-segregational tendencies - either directly or indirectly through increased feelings of inauthenticity. Future research should explore the role of variables like these to come to yet a more complete understanding of the discrimination-segregation connection.

Thirdly, future research should investigate further possible associations between authenticity and immigrants' friendship formation processes. Our research suggests that feelings of decreased authenticity in interactions with majority members are connected to migrants' lower mental and behavioral tendencies to befriend them. At the same time, feelings of inauthenticity may also affect social interactions in a way that decreases the conversation partner's willingness to pursue a friendship. Previous research has found that individuals who feel inauthentic show less extraversion, agreeableness, and openness (Fleeson \& Wilt, 2010; Sheldon, Ryan, Rawsthorne, \& Ilardi, 1997), but heightened self-monitoring (Lenton et al., 2013). Inauthentic feelings thus seem to translate into a more restricted and less smooth interaction dynamic which may put off research.

Finally, future work should develop and test potential interventions that could buffer the detrimental effects of discrimination on social integration. Two broad approaches are conceivable: Firstly, interventions could strengthen individuals' sense of authenticity in such a way that they can sustain feelings of authenticity in the face of discrimination. This could be done by psychological interventions (e.g., helping individuals make sense of discrimination experiences in an adaptive way, illustrating how single instances of discrimination do not imply individuals' rejection by the host society as a whole) and/or by creating identity-safe contexts (Hall et al., 2018) that make individuals (including their social identity) feel accepted and allow for authentic inter-ethnic interactions. Secondly, interventions could also aim to weaken the link between inauthenticity and avoidance of contact with natives. Single instances of feelings of inauthenticity seem to be a normal part of life (Lenton et al., 2013) - and may be even more so in the initial stage 
of getting used to a new cultural environment. Maybe interventions that illustrate how feelings of authenticity can be developed over time and are not definite indicators of one's belonging in a certain environment could reduce adverse effects of inauthenticity, help individuals sustain their engagement with natives and develop a sense of authenticity on the long run.

\section{Conclusion}

The recent influx of refugees in the western world has sparked a rise in anti-immigrant hostility including rising discrimination (Rooduijn, 2015; Tynes, Seaton, \& Zuckerman, 2015). Our research indicates that discrimination may interfere with refugees' social integration process by making them feel inauthentic in interactions with natives. Conversely, finding ways that help strengthen their relationships with the native population in their new homes.

\section{References}

Aboud, F., Mendelson, M., \& Purdy, K. (2003). Cross-race peer relations and friendship quality. International Journal of Behavioral Development, 27, 165-173. https://doi.org/10.1080/ 01650250244000164

Baerveldt, C., Van Duijn, M. A., Vermeij, L., \& Van Hemert, D. A. (2004). Ethnic boundaries and personal choice. Assessing the influence of individual inclinations to choose intra-ethnic relationships on pupils' networks. Social Networks, 26, 55-74. https://doi.org/10.1016/j.socnet.2004.01.003

Bauer, C. A., \& Hannover, B. (2020). Changing "us" and hostility towards "them" - Implicit theories of national identity determine prejudice and participation rates in an anti-immigrant petition. European Journal of Social Psychology, 50, 810-826. https://doi.org/10.1002/ejsp.2666

Berry, J. W., Phinney, J. S., Sam, D. L., \& Vedder, P. (2006). Immigrant youth: Acculturation, identity, and adaptation. Applied Psychology, 55, 303-332. https://doi.org/10.1111/ j.1464-0597.2006.00256.x

Bonilla-Silva, E., \& Embrick, D. G. (2007). "Every place has a ghetto...": The significance of whites' social and residential segregation. Symbolic Interaction, 30, 323-345. https://doi.org/ 10.1525/si.2007.30.3.323

Borsch, A. S., de Montgomery, C. J., Gauffin, K., Eide, K., Heikkilä, E., \& Smith Jervelund, S. (2019). Health, education and employment outcomes in young refugees in the nordic countries: A systematic review. Scandinavian Journal of Public Health, 47, 735-747. https://doi.org/10.1177/1403494818787099

Bourdieu, P. (1987). Die feinen Unterschiede: Kritik der gesellschaftlichen Urteilskraft [Subtle differences: Critique of the societal power of judgment]. Berlin, Germany: Suhrkamp.

Branscombe, N. R., Schmitt, M. T., \& Harvey, R. D. (1999). Perceiving pervasive discrimination among African Americans: Implications for group identification and well-being. Journal of Personality and Social Psychology, 77, 135. https://doi.org/ 10.1037/0022-3514.77.1.135

Brauer, M., \& Er-Rafiy, A. (2011). Increasing perceived variability reduces prejudice and discrimination. Journal of Experimental Social Psychology, 47, 871-881. https://doi.org/10.1016/j.jesp. 2011.03.003
Brody, G. H., Chen, Y. F., Murry, V. M., Ge, X., Simons, R. L., Gibbons, F. X., ... Cutrona, C. E. (2006). Perceived discrimination and the adjustment of African American youths: A five-year longitudinal analysis with contextual moderation effects. Child development, 77, 1170-1189. https://doi.org/10.1111/j.14678624.2006.00927.x

Castillo, L. G., Cano, M. A., Chen, S. W., Blucker, R. T., \& Olds, T. S (2008). Family conflict and intragroup marginalization as predictors of acculturative stress in Latino college students. International Journal of Stress Management, 15, 43-52. https://doi.org/10.1037/1072-5245.15.1.43

Cheryan, S. (2012). Understanding the paradox in math-related fields: Why do some gender gaps remain while others do not? Sex Roles, 66, 184-190. https://doi.org/10.1007/s11199-0110060-z

Cheryan, S., Drury, B. J., \& Vichayapai, M. (2013). Enduring influence of stereotypical computer science role models on women's academic aspirations. Psychology of Women Quarterly, 37, 72-79. https://doi.org/10.1177/0361684312459328

Cheryan, S., Plaut, V. C., Davies, P. G., \& Steele, C. M. (2009). Ambient belonging: How stereotypical cues impact gender participation in computer science. Journal of Personality and Social Psychology, 97, 1045-1060. https://doi.org/10.1037/ a0016239

da Silva Rebelo, M. J., Fernández, M., \& Achotegui, J. (2018). Mistrust, anger, and hostility in refugees, asylum seekers, and immigrants: A systematic review. Canadian Psychology, 59, 239-251. https://doi.org/10.1037/cap0000131

Didonato, T. E., \& Krueger, J. I. (2010). Interpersonal affirmation and self-authenticity: A test of Rogers's self-growth hypothesis. Self and Identity, 9, 322-336. https://doi.org/10.1080/ 15298860903135008

Diehl, C., Fischer-Neumann, M., \& Mühlau, P. (2016). Between ethnic options and ethnic boundaries - Recent Polish and Turkish migrants' identification with Germany. Ethnicities, 16, 236-260. https://doi.org/10.1177/1468796815616156

English, T., \& John, O. P. (2013). Understanding the social effects of emotion regulation: The mediating role of authenticity for individual differences in suppression. Emotion, 13, 314. https:// doi.org/10.1037/a0029847

Esser, H. (2001). Integration und ethnische Schichtung [Integration and ethnic stratification]. Mannheim, Germany: Mannheimer Zentrum für Europäische Sozialforschung. Retrieved from http:// edoc.vifapol.de/opus/volltexte/2014/5134/pdf/wp_40.pdf

Faul, F., Erdfelder, E., Lang, A. G., \& Buchner, A. (2007). G*Power 3: A flexible statistical power analysis program for the social, behavioral, and biomedical sciences. Behavior Research Methods, 39, 175-191. https://doi.org/10.3758/bf03193146

Fleeson, W., \& Wilt, J. (2010). The relevance of Big Five trait content in behavior to subjective authenticity: Do high levels of withinperson behavioral variability undermine or enable authenticity achievement? Journal of Personality, 78, 1353-1382. https://doi. org/10.1111/j.1467-6494.2010.00653.x

Franco, M. (2019). Let the racism tell you who your friends are: The effects of racism on social connections and life-satisfaction for multiracial people. International Journal of Intercultural Relations, 69, 54-65. https://doi.org/10.1016/j.ijintrel.2018.12.005

German Federal Anti-Discrimination Agency. (2017). Diskriminierung in Deutschland [Discrimination in Germany]. Retrieved from https:// www.antidiskriminierungsstelle.de/SharedDocs/Downloads/DE/ publikationen/BT_Bericht/Gemeinsamer_Bericht_dritter_2017. html

German Federal Ministry of the Interior. (2016). Verfassungsschutzbericht 2015 [Defense of the Constitution Report 2015]. Retrieved from https://www.verfassungsschutz.de/download/ vsbericht-2015.pdf 
Gibbons, F. X., Gerrard, M., Cleveland, M. J., Wills, T. A., \& Brody, G. (2004). Perceived discrimination and substance use in African American parents and their children: A panel study. Journal of Personality and Social Psychology, 86, 517-529. https://doi.org/ 10.1037/0022-3514.86.4.517

Gillath, O., Sesko, A. K., Shaver, P. R., \& Chun, D. S. (2010). Attachment, authenticity, and honesty: Dispositional and experimentally induced security can reduce self-and otherdeception. Journal of Personality and Social Psychology, 98, 841855. https://doi.org/10.1037/a0019206

Hall, W., Inness, M., Schmader, T., Aday, A., \& Croft, E. (2018). Climate control: The relationship between social identity threat and cues to an identity-safe culture. Journal of Personality and Social Psychology, 115, 446-467. https://doi.org/10.1037/ pspi0000137

Hangartner, D., Dinas, E., Marbach, M., Matakos, K., \& Xefteris, D. (2019). Does exposure to the refugee crisis make natives more hostile? American Political Science Review, 113, 442-455. https://doi.org/10.1017/s0003055418000813

Harter, S. (2002). Authenticity. In C. R. Snyder \& S. J. Lopez (Eds.), Handbook of positive psychology (pp. 382-394). New York, NY: Oxford University Press.

Harter, S., Marold, D. B., Whitesell, N. R., \& Cobbs, G. (1996). A model of the effects of perceived parent and peer support on adolescent false self behavior. Child Development, 67, 360374. https://doi.org/10.1111/j.1467-8624.1996.tb01738.x

Hewstone, M. (2015). Consequences of diversity for social cohesion and prejudice: The missing dimension of intergroup contact. Journal of Social Issues, 71, 417-438. https://doi. org/10.1111/josi.12120

Hindricks, P., Verkuyten, M., \& Coenders, M. (2014). Interminority attitudes: The roles of ethnic and national identification, contact, and multiculturalism. Social Psychology Quarterly, 77, $54-74$.

Hoare, R. (2019). "I can only be properly myself when I'm with her": Early adolescent intra-ethnic immigrant group friendships as a safe space for identity exploration, negotiation and validation. Childhood, 26, 202-220. https://doi.org/10.1177/ 0907568218824389

Ihlanfeldt, K. R., \& Scafidi, B. (2002). Black self-segregation as a cause of housing segregation: Evidence from the multi-city study of urban inequality. Journal of Urban Economics, 51, 366-390. https://doi.org/10.1006/juec.2001.2249

Jasinskaja-Lahti, I., Liebkind, K., \& Solheim, E. (2009). To Identify or not to identify? National disidentification as an alternative reaction to perceived ethnic discrimination. Applied Psychology, 58, 105-128. https://doi.org/10.1111/j.1464-0597.2008.00384.x

Josephs, L., Warach, B., Goldin, K. L., Jonason, P. K., Gorman, B. S., Masroor, S., \& Lebron, N. (2019). Be yourself: Authenticity as a long-term mating strategy. Personality and Individual Differences, 143, 118-127. https://doi.org/10.1016/j.paid.2019.02.020

Kamans, E., Gordijn, E. H., Oldenhuis, H., \& Otten, S. (2009). What I think you see is what you get: Influence of prejudice on assimilation to negative meta-stereotypes among Dutch Moroccan teenagers. European Journal of Social Psychology, 39, 842-851. https://doi.org/10.1002/ejsp.593

Kernis, M. H., \& Goldman, B. M. (2006). A multicomponent conceptualization of authenticity: Theory and research. Advances in Experimental Social Psychology, 38, 283-357. https://doi.org/10.1016/S0065-2601(06)38006-9

Lancee, B. (2012). The economic returns of bonding and bridging social capital for immigrant men in Germany. Ethnic and Racial Studies, 35, 664-683. https://doi.org/10.1080/01419870.2011. 591405

Lancee, B., \& Hartung, A. (2012). Turkish migrants and native Germans compared: The effects of inter-ethnic and intra-ethnic friendships on the transition from unemployment to work. International Migration, 50, 39-54. https://doi.org/10.1111/ j.1468-2435.2011.00736.x

Leak, G. K., \& Cooney, R. R. (2001). Self-determination, attachment styles, and well-being in adult romantic relationships. Representative Research in Social Psychology, 25, 55-62. Retrieved from http://selfdeterminationtheory.org/SDT/documents/2001_LeakCooney_RRSP.pdf

Lenton, A. P., Bruder, M., Slabu, L., \& Sedikides, C. (2013). How does "being real" feel? The experience of state authenticity. Journal of Personality, 81, 276-289. https://doi.org/10.1111/ j.1467-6494.2012.00805.x

Leszczensky, L., \& Pink, S. (2017). Intra- and inter-group friendship choices of Christian, Muslim, and non-religious youth in Germany. European Sociological Review, 33, 72-83. https://doi. org/10.1093/esr/jcw049

Levin, S., Van Laar, C., \& Foote, W. (2006). Ethnic segregation and perceived discrimination in college: Mutual influences and effects on social and academic life 1. Journal of Applied Social Psychology, 36, 1471-1501. https://doi.org/10.1111/j.00219029.2006.00068.x

Levin, S., Van Laar, C., \& Sidanius, J. (2003). The effects of ingroup and outgroup friendships on ethnic attitudes in college: A longitudinal study. Group Processes \& Intergroup Relations, 6, 76-92. https://doi.org/10.1177/1368430203006001013

Livingston, R. W., \& Drwecki, B. B. (2007). Why are some indi -viduals not racially biased? Susceptibility to affective conditioning predicts nonprejudice toward Blacks. Psychological Science, 18, 816-823. https://doi.org/10.1111/j.1467-9280. 2007.01985.x

Lopez, F. G., \& Rice, K. G. (2006). Preliminary development and validation of a measure of relationship authenticity. Journal of Counseling Psychology, 53, 362-371. https://doi.org/10.1037/ 0022-0167.53.3.362

Lyons-Padilla, S., Gelfand, M. J., Mirahmadi, H., Farooq, M., \& Van Egmond, M. (2015). Belonging nowhere: Marginalization \& radicalization risk among Muslim immigrants. Behavioral Science \& Policy, 1, 1-12.

Martiny, S. E., \& Nikitin, J. (2019). Social identity threat in interpersonal relationships: Activating negative stereotypes decreases social approach motivation. Journal of Experimental Psychology: Applied, 25, 117-128. https://doi.org/10.1037/ xap0000198

Matschke, C., \& Sassenberg, K. (2010). Does rejection lead to disidentification? The role of internal motivation and avoidance strategies. European Journal of Social Psychology, 40, 891-900. https://doi.org/10.1002/ejsp.756

McCarthy, N. (2018, June 29). Germany is home to the most refugees. Statista. Retrieved from https://www.statista.com/ chart/14494/germany-is-home-to-the-most-refugees/

Merz, E. M., \& Huxhold, O. (2010). Wellbeing depends on social relationship characteristics: Comparing different types and providers of support to older adults. Ageing \& Society, 30, 843857. https://doi.org/10.1017/s0144686×10000061

Murphy, M. C., Steele, C. M., \& Gross, J. J. (2007). Signaling threat: How situational cues affect women in math, science, and engineering settings. Psychological science, 18, 879-885.

Neske, M. (2017). BAMF-Kurzanalyse [short report]. German Federal Agency of Migration and Refugees. Retrieved from http://www.bamf.de/SharedDocs/Anlagen/DE/Publikationen/ Kurzanalysen/kurzanalyse8_sozial-komponentengesamt2016.pdf?_blob=publicationFile

Oettingen, G., \& Mayer, D. (2002). The motivating function of thinking about the future: Expectations versus fantasies. Journal of personality and social psychology, 83, 1198. https://doi.org/10.1037/0022-3514.83.5.1198 
Pahl, K., \& Way, N. (2006). Longitudinal trajectories of ethnic identity among urban Black and Latino adolescents. Child Development, 77, 1403-1415. https://doi.org/10.1111/j.14678624.2006.00943.x

Peterson, T., \& Morgan, L. A. (1995). Separate and unequal: Occupation-establishment sex segregation and the gender wage gap. The American Journal of Sociology, 101, 329-365. https://doi.org/10.1086/230727

Pettigrew, T. F., \& Tropp, L. R. (2006). A meta-analytic test of intergroup contact theory. Journal of Personality and Social Psychology, 90, 751. https://doi.org/10.1037/0022-3514.90.5.751

Preacher, K. J., \& Hayes, A. F. (2004). SPSS and SAS procedures for estimating indirect effects in simple mediation models. Behavior Research Methods, Instruments, \& Computers, 36, 717-731. https://doi.org/10.3758/bf03206553

Purdie-Vaughns, V., Steele, C. M., Davies, P. G., Ditlmann, R., \& Crosby, J. R. (2008). Social identity contingencies: How diversity cues signal threat or safety for African Americans in mainstream institutions. Journal of Personality and Social Psychology, 94, 615-630. https://doi.org/10.1037/0022-3514.94.4.615

Ramos, M. R., Cassidy, C., Reicher, S., \& Haslam, S. A. (2012). A longitudinal investigation of the rejection-identification hypothesis. British Journal of Social Psychology, 51, 642-660. https:// doi.org/10.1111/j.2044-8309.2011.02029.x

Rooduijn, M. (2015). The rise of the populist radical right in Western Europe. European View, 14, 3-11. https://doi.org/ $10.1007 /$ s12290-015-0347-5

Roth, T. (2013). The Role of Social Capital in the Explanation of Educational Success and Educational Inequalities. Irish Educational Studies, 32, 335-354. Retrieved from http://search. ebscohost.com/login.aspx?direct=true\& $\mathrm{db}=$ eric $\& A N=$ EJ1021495\&site=ehost-live

Scheible, J. A. (2018, March 16). Alphabetisierung und Deutscherwerb von Geflüchteten: Deutschkenntnisse und Förderbedarfe von Erst- und Zweitschriftlernenden in Integrationskursen [Literacy and language acquisition of refugees: Language proficiency and support needs of first and second copy learners in integration courses]. German Federal Agency of Migration and Refugees. Retrieved from http://www.bamf.de/SharedDocs/Anlagen/DE/ Publikationen/Kurzanalysen/kurzanalyse10_iab-bamf-soepbefragung-gefluechtete-alphabetisierung.html

Schmader, T., \& Sedikides, C. (2018). State authenticity as fit to environment: The implications of social identity for fit, authenticity, and self-segregation. Personality and Social Psychology Review, 22, 228-259. https://doi.org/10.1177/1088868317734080

Sheldon, K. M., Ryan, R. M., Rawsthorne, L. J., \& Ilardi, B. (1997). Trait self and true self: Cross-role variation in the Big-Five personality traits and its relations with psychological authenticity and subjective well-being. Journal of Personality and Social Psychology, 73, 1380. https://doi.org/10.1037/0022-3514.73. 6.1380

Shelton, J. N., Richeson, J. A., \& Salvatore, J. (2005). Expecting to be the target of prejudice: Implications for interethnic interactions. Personality and Social Psychology Bulletin, 31, 11891202. https://doi.org/10.1177/0146167205274894

Snyder, M. (1987). Public appearances/private realities: The psychology of self-monitoring. San Francisco, CA: Freeman.

Suleman, S., Garber, K. D., \& Rutkow, L. (2018). Xenophobia as a determinant of health: An integrative review. Journal of Public Health Policy, 39, 407-423. https://doi.org/10.1057/s41271018-0140-1

Swann, W. B. Jr., De La Ronde, C., \& Hixon, J. G. (1994). Authenticity and positivity strivings in marriage and courtship. Journal of Personality and Social Psychology, 66, 857-869. https://doi.org/10.1037/0022-3514.66.5.857
Tajfel, H., \& Turner, J. C. (1979). An integrative theory of intergroup conflict. In W. G. Austin \& S. Worchel (Eds.), The social psychology of intergroup relations (pp. 33-47). Monterey, CA: Wadsworth. https://doi.org/10.4324/9780203505984-16

Titzmann, P. F. (2014). Immigrant adolescents' adaptation to a new context: Ethnic friendship homophily and its predictors. Child Development Perspectives, 8, 107-112. https://doi.org/ $10.1111 /$ cdep.12072

Titzmann, P. F. (2017). Interethnic friendship formation. In N. J. Cabrera \& B. Leyendecker (Eds.), Handbook on positive development of minority children and youth (pp. 249-266) https:// doi.org/10.1007/978-3-319-43645-6_15. New York, NY: Springer Science + Business Media

Titzmann, P. F., Serwata, O. J., Silbereisen, R. K., \& Davidov, E. (2016). A comparative perspective on mothers' ethnic homophily among minority groups in Germany and Israel. Journal of Cross-Cultural Psychology, 47, 1076-1096. https://doi.org/ 10.1177/0022022116658245

Titzmann, P. F., \& Silbereisen, R. K. (2009). Friendship homophily among ethnic German immigrants: A longitudinal comparison between recent and more experienced immigrant adolescents. Journal of Family Psychology, 23, 301-310. https://doi.org/ 10.1037/a0015493

Titzmann, P. F., Silbereisen, R. K., \& Mesch, G. S. (2012). Change in friendship homophily: A German Israeli comparison of adolescent immigrants. Journal of Cross-Cultural Psychology, 43, 410-428. https://doi.org/10.1177/0022022111399648

Titzmann, P. F., Silbereisen, R. K., \& Schmitt-Rodermund, E. (2007). Friendship homophily among diaspora migrant adolescents in Germany and Israel. European Psychologist, 12, $181-$ 195. https://doi.org/10.1027/1016-9040.12.3.181

Tugade, M. M., Shiota, M. N., \& Kirby, L. D. (Eds.). (2014). Handbook of positive emotions. New York, NY: Guilford Press.

Tynes, B. M., Seaton, E., \& Zuckerman, A. (2015). Online racial discrimination: A growing problem for adolescents. Psychological Science Agenda. Retrieved from https://www.apa.org/science/ about/psa/2015/12/online-racial-discrimination

United Nations High Commissioner for Refugees. (2019). Refugee Statistics. Retrieved from https://www.unrefugees.org/refugee-facts/statistics

Verkuyten, M., \& Yildiz, A. A. (2007). National (dis) identification and ethnic and religious identity: A study among Turkish-Dutch Muslims. Personality and Social Psychology Bulletin, 33, 14481462. https://doi.org/10.1177/0146167207304276

Walton, G. M., \& Cohen, G. L. (2007). A question of belonging: Race, social fit, and achievement. Journal of Personality and Social Psychology, 92, 82. https://doi.org/10.1037/00223514.92.1.82

Werum, R. E. (2000). The ethnic dimensions of social capital: How parental networks shape track placement in Germany. Retrieved from http://search.ebscohost.com/login.aspx?direct $=$ true\&db=eric \&AN=ED440762\&site=ehost-live

Yip, T., Wang, Y., Mootoo, C., \& Mirpuri, S. (2019). Moderating the association between discrimination and adjustment: A metaanalysis of ethnic/racial identity. Developmental Psychology, 55, 1274-1298. https://doi.org/10.1037/dev0000708

\section{History}

Received March 26, 2020

Revision received May 29, 2020

Accepted June 4, 2020

Published online July 9, 2020 


\section{Acknowledgments}

This work was supported by a grant of the "Studienstiftung des Deutschen Volkes" allocated to the first author.

\section{Conflict of Interest}

The authors declare that they have no conflict of interest.

\section{Authorship}

Christina Anna Bauer and Bettina Hannover designed the research and wrote the paper; Christina Anna Bauer performed the research and analyzed the data.

\section{Open Data}

Materials (including all translations) as well as data are available on the Open Science Framework https://osf.io/ks9mu/? view_only $=65843002 d 32 d 4 c f 58 a d f 3 d 7 f 94 d 7 c b c 2$

\section{ORCID}

Christina Anna Bauer

(iD https://orcid.org/0000-0002-9042-2965

\section{Christina Anna Bauer}

Department of Educational Science and Psychology

Freie Universität Berlin

Habelschwerdter Allee 45

Raum JK 24/222e

14195 Berlin

Germany

christina.bauer@fu-berlin.de 